Review

\title{
Heteroatom-Doped Carbon Materials as Support for Anode Electrocatalysts for Direct Formic Acid Fuel Cells
}

\author{
SK Safdar Hossain \\ Department of Chemical Engineering, College of Engineering, King Faisal University, P.O. Box:380, \\ Al-Ahsa-31982, Kingdom of Saudi Arabia \\ E-mail: snooruddin@kfu.edu.sa
}

doi: $10.20964 / 2021.01 .32$

Received: 11 September 2020 / Accepted: 8 November 2020 / Published: 30 November 2020

\begin{abstract}
Direct formic acid fuel cells (DFAFCs) are a viable energy source for electronic devices and transportation. The bottleneck in the commercialization of DFAFCs is the limited power-density output owing to the slow kinetics of electro-oxidation of formic acid at the anode. Platinum and palladium-based nanomaterials are found to be active for formic acid oxidation. However, they show limited mass activity and insufficient long-term stability. The structure-activity relationship for electrocatalysts is now well established. The large-scale synthesis of electrocatalysts containing well dispersed, optimum sized noble metal nanoparticles with desired surface properties is relatively challenging. The nature of the support of an electrocatalyst influences the morphology and structure (shape, size, and dispersion of the active noble metals) and chemical properties through interaction between the metal and support, as well as electronic effect. Materials with tailored physical properties such as surface area, pore structure, pore-size distribution, and electrical conductivity are deemed ideal supports for electrocatalysts. Introducing desired functional groups and defects can effectively tune the surface and electronic properties of the support further. Various novel carbon materials and their chemically modified forms have been explored as support materials for DFAFCs. In this review article, the latest developments in the synthesis, characterization, and performance of heteroatomdoped carbon materials as support material for anode electrocatalysts in DFAFCs are summarized. Directions for future research are presented based on the critical analysis of the present research in materials for DFAFCs.
\end{abstract}

Keywords: Nanostructured carbon materials; Heteroatom-doped carbon nanomaterials; Effect of support materials; Anode electrocatalysts; Enhancement mechanism; Direct formic acid fuel cells;

\section{$\underline{\text { FULL TEXT }}$}


(C) 2021 The Authors. Published by ESG (www.electrochemsci.org). This article is an open access article distributed under the terms and conditions of the Creative Commons Attribution license (http://creativecommons.org/licenses/by/4.0/). 